\title{
THE UKRAINIAN AUTOBIOGRAPHICAL ESSAY: THE HISTORY OF DEVELOPMENT
}

\begin{abstract}
Summary. The article is devoted to the study of the history of the Ukrainian autobiographical essays development. It is noted than the genre of autobiographical essay in the Ukrainian literature dates back to the XVI century, from the time of the appearance of the Latin autobiographical essay by Stanyslav Orikhovskii (Roksolan). Later, this genre was presented at all historical stages of the Ukrainian literature development. The article analyses autobiographical essays by Taras Shevchenko, Oleksandr Potebnia, Stepan Vasylchenko, Maik Johansen, Oleksandr Dovzhenko, Hryhor Tiutiunnyk, and others. The pragmatic purpose of writing essays is indicated, on which the choice of the form, structure and degree of literary of the essay depended. For centuries, the Ukrainian autobiographical essays were represented by factual, scientific, biobibliographic, game, typed, apologetic varieties. Characteristic of this genre were a small volume of autobiographical narrative, free composition, lack of generally accepted rules of construction, pragmatic instruction of the narrative, a strong personal beginning, factuality, documentary. Most Ukrainian autobiographical essays were written for apologetic or cognitive purposes. Autobiographical essay of the turn of the XIX-XX centuries were, for the most part, literary centric. It was not uncommon for authors to repeatedly address this genre, written at short intervals for different recipients. Autobiographical essays of this period were often censored and edited. The genre flourished in the 1920s. Essays of this period freely expressed their thoughts, autobiographical essays were a means of self-expression of writers. Motives of self-remorse and selfaccusation were characteristic of Ukrainian autobiographical essays of the 1930s and 1950s. Most of autobiographical essays of the 1930s and 1960s were typified and apologetic. Since the 1990s, Ukrainian autobiographical essays have become more informative.
\end{abstract}

Key words: autobiographical essay, the Ukrainian autobiographical writing, scientific autobiographical essay, literary autobiographical essay, pragmatics object, factography, apologetics.

Problem statement. The Ukrainian autobiographical essay dates back to the XVI century. Since that time it retains its essential features, which help to identify it as a small genre of autobiographical prose, as a brief history written with a purely pragmatic goal that gives some general idea about the autobiographer's life; describes his personality traits; presents his ideological, social, political, aesthetic and other preferences. Works of this genre do not have generally recognized rules of the author's self-presentation, they are marked with a free composition, that in most cases reflects the author's pragmatic settings. However, the main in this genre is the fact that it has the person-oriented core. Autobiographical essay is quite a common genre of the Ukrainian autobiographical prose and its representative samples can be found at all the stages of the Ukrainian memoir writing development. But till today we haven't had any special literary research devoted to this genre study.

Analysis of recent research and publications. As for the Ukrainian autobiographical essay itself, in home literary critics define it as autobiography (the works by R. Movchan [1] and others), autobiographical story, or generally it isn't described as a separate genre of personal memories literature (as, for example, it is said in the works of M. Fedun [2] and others). In the already existing reviews of the Ukrainian memoir writing of the XIX-XXI centuries (in particular, in the researches by O. Halych [3], V. Pustovit [4], and others), we can find only single mentions of individual essays (basically, it is about the essays by Ivan Franko, Olha Kobylianska, Valerian Polishchuk, Ostap Vyshnia, Oleksandr Dovzhenko, etc.), while the rest of the vast array of Ukrainian autobiographical essays today remains outside of the scientific interest. And it's so regrettable because an autobiographical essay not only provides some important facts about living existence and inner psychological essence of autobiographical writer, but comes to be one of the most mobile genres, that greatly reflects the ruling ideological, intellectual and other moods [5-6]. That is why studying this genre is relevant today and it requires a more careful literary research.

The objective of the article. The aim of our article is considering the history of the Ukrainian autobiographical essay on different stages of its evolutionary path.

Discussions. One of the first representative samples of this genre was the autobiographical essay (1564) by Stanyslav Orikhovsky (Roksolan), placed in his letter to Cardinal Jan Francis Commendoni (the Pope's Nuncio in Poland during the 1563-1565 and 1571-1573). The essay had a strong pragmatic character and the main purpose of that writing was the author's attempt to escape misunderstanding and misinterpretation of his actions and some publicly expressed religious beliefs. To justify, and in such a way, to save himself from slander, the author wrote the autobiographical essay in which he presented his own vision of his life, confessed his sins and explained his own life position. Thus, already in the XVI century one of the pragmatic goals of the autobiographical essay genre manifested and it was presenting an author's own life vision and his philosophical beliefs to the readers in order to justify himself.

Another pragmatic aim was found in Taras Shevchenko's autobiographical essay (1860), which was put in the open letter to "The Peoples' Reading" chief editor. The main Taras Shevchenko's desire was to attract public attention to the problem of serfdom. On the example of his own life, the artist showed all the difficulties of the talents development of an outstanding personality when there was no personal freedom. As Taras Shevchenko remarked in his essay, he personally, with the support of his friends, finally managed 
to get the desired freedom and continue his spiritual and artistic development, but a lot of his talented compatriots didn't have such opportunities. And therefore, Taras Shevchenko's autobiographical essay went far beyond the narrow limits of a detailed self-description and acquired polemical journalistic acuity to draw attention to the most painful issues for the contemporary society of that time. This intention to draw the attention to actual problems of modern author's life will soon be shown in other autobiographical essays not only in the XIX, but also in the XX and XXI centuries (for example, in the autobiographical essays by Natalia Kobrynska, Olena Pchylka, Hryhir Tiutiunnyk, Oksana Zabuzhko and others). Taras Shevchenko's autobiographical essay was the first to start one more tendency typical of this genre, that is: editorial correction of essays, in accordance with the needs of publishers and state ideological settings. Sometimes that led to significant transformation of the text not only from the ideological point of view, but also because of the autobiographical facts, as, for example, in Olena Pchylka's autobiographical essay which was only partially written by the author, and then, with a significant shift of the main accents of the autobiographical narrative, was supplemented by the editor. As for Taras Shevchenko's autobiographical essay, it is also known in two versions - before and after Panteleimon Kulish's censorship.

In the second half of the XIX century, a new typological variety of the genre - a scientific autobiographical essay, presented at that time Oleksandr Potebnia's, appears. The main purpose of that writing was the brief information of biobibliographical nature with an emphasis on the author's own intellectual development, his scientific work and the like. Kost Mykhalchuk's and Volodymyr Antonovych's autobiographical essays, written at the beginning the twentieth century, expanded the subjects of a scientific essay by introducing information about their own scientific, educational and ethnographic activities.

At the end of the XIX century begins another fairly common in the Ukrainian autobiographical prose typological variety of the genre appears - this is a writer's autobiographical essay which is written with the purpose of presenting some author's basic biographical, bibliographical and literary-critical information to numerous writing activity researchers, publishers, Ukrainian literature history researchers, compilers of literature bibliographical references and encyclopedias, etc.

So, at the turn of XIX-XX centuries the autobiographical essays by Natalia Kobrynska, Ivan Franko, Olha Kobylianska and others were written and partially published. The peculiarity of these works was that, as a rule, the authors repeatedly appealed to their autobiographical essays written for different addressees, and therefore, each new essay was not identical to the previous one, but it added some new details from the author's private and artistic life to the written before. In particular a number of various, including apologetic, autobiographical essays were created by Ivan Franko, for example: "Ivan Franko's Autobiography Taken from His Letter to M. Drahomanov" (1890), "Ivan Franko's Autobiography Written for Om. Ohonovskyi"; "Some Facts about Myself" written in Polish as a preface to the Polish Ivan Franko's stories "Obraski galicyjskie", that was published in Lviv in 1897; the autobiographical essay for the editor of "Herder's Lexicon", and others. A number of interesting essays about her own life and her "psyche" was presented by Olha Kobylianska, who at different times wrote the autobiographical essays for F. Rzhegorzh, P. Todorov, S. Smal-Stotskyi and others. This tradition of the diverse coverage of the authors' internal and external "I" was later extended in the autobiographical essays by Mike Yohansen, Ostap Vyshnia and other writers.

During the 1920 s the genre was really flourishing. At that time autobiographical essays were written not only by the writers of the "older generation" (as, for example, Vasyl Stefanyk, Marko Cheremshyna, Olha Kobylianska, Hnat Hotkevych, Olena Pchylka), but also by the writers who just started their career (Valeriian Polishchuk, Mike Yohansen, Ostap Vyshnia, and others).

And if the writers of the older generation modeled mainly the archetypal image of a rural writer who lived in complete harmony with nature, was detached from the big world and wrote his works, first of all, in his own pleasure (we wrote more about this in our previous scientific research), then for young writers who only entered the literature genre of the autobiographical essay writing became one of ways of their self-expression.

The irony, wit, ease of writing combined with a deep introspection became the autobiographical essays visiting-cards of contemporary young writers in that time. The essayists added various kinds of literary mystification and games with the reader to this genre, self-irony, which, in most cases, performed a protective function, became widespread. They wrote in such a way because not serious, playful form of life self-description gave writers the ability to hide his present "self", avoid the "slippery" topics and facts of his own biography. The greatest extent this is reflected in Mike Yohansen's and Ostap Vyshnia's autobiographical essays, who conscientiously hid their I under the guise of a jester, because, as the Ukrainian researcher R. Movchan reasonably wrote, "of course, we should take into consideration the fact that time, when these autobiographies were written - it was the mid 20s, and it demanded to represent the mask, but not the true face" [7, p. 29]. In this respect M. Yohansen's self-description seems to be rather illustrative he put it in the autobiographical essay "The Autobiography of Mike Yohansen, the Yohansen who implemented the prologue, the epilogue and interludes the 133-rd book of "The Literary Fain»": "Being a poet, a writer, a novelist, a linguist, the author of grammars, books of poems, dictionaries, numerous translations from all peoples' languages of the world, in the middle of my life also wrote extensive comments to the comments of the great philosopher Averoes and that made my name immortal for one more time" $[8$, p. 718$]$.

But at the same time their diverse autobiographical essays were focused on showing the atmosphere "of that difficult time" $[1, \mathrm{p} .79]$ as precise as possible. As R. Movchan notes: "Fixing for the history each artist's contribution, and, in general, testifying the full genesis of the Ukrainian literature was probably the most important component of public consciousness of that time" $[1, p .79]$. The autobiographical essays of the younger generation writers had great dynamism, the panoramic view of life depiction that raged around them, it was also defined with the revolutionary romanticism, vital optimism and faith in a better future thanks to their untiring work. "Now it is the time of the Ukrainian Renaissance, and, as Leites wrote, a prolific day. We came to work, not to nail polish. We came to give a job, a lot of food, not to refine" [9, p. 25], as Valeriian Polishchuk determined those days essayists' credo.

In that period, they still had the opportunity to write frankly about their social origin, their Ukrainian-centered citizenship opinion, about their membership in non-Bolsheviks parties and forces, etc., as, for example, Olena Pchylka, Hnat Hotkevych, Valeriian Polishchuk and others did. However already at that time in the autobiographical essays writing of the young generation authors the tendency towards 
a cursory description of their biographical facts, mentioning of which could negatively affect the further existence of the authors, their families and friends, began to take shape.

A lot of writers' autobiographical essays of that period were written at the request of Mykola Plevako, who collected the material for thorough biobibliographical dictionary of Ukrainian writers. So, for that edition Hrytsko Koliada, Mike Yohansen, Olelko Korzh, Oleksandr Kovinka, Mikhailo Ivchenko, Vasil Mysyk, Liudmyla Starytska-Cherniakhivska and others wrote their autobiographical essays. In most cases, the authors tried to objectively show themselves as writers and artists, thanks to what in the forefront of their autobiographical essays was a factual component, although some authors do not exclude the possibility to add some game effect to them (as, for example, Olelko Korzh did). Unfortunately, the project with the compilation of the dictionary wasn't brought to its logical end, because in 1938 Mykola Plevako was arrested and in three years he died in exile. The materials collected by him (official-business autobiographies, questionnaires, autobiographical essays, etc.) eventually ended in the archives. Thanks to the tireless work of R. Movchan they were researched and partially published.

The Ukrainian autobiographical essays of 1930s had quite different, primarily ideological sense. The individual moments, which severely exterminated from literature at that time, began to vanish. Instead mandatory for the Soviet period memoir literature typing appeared resulted in showing autobiographers' lives as typical for the people of their time and their social class. For example, Stepan Vasylchenko in his autobiographical essay "My Way" draws a typical portrait of a Ukrainian national teacher who always dwelt among common people and knew all people's pains and problems.

Already in Stepan Vasylchenko's autobiographical essay a widespread in the Soviet autobiographical literature tradition of public self-justification and self-repentance exhibited and could be defined as the motif of "pre-set fault".

Perhaps the greatest degree of this motif was shown in the so-called "prison cell" autobiographical essays that were written in prisons under the supervision of the GPU inspectors. These texts were written in prison under the supervision were often "processed", according to O. and L. Ushkalov, were not the authors' life descriptions but "largely they became the memories of the GPU employees bloody creativity" [10, p. 6-7].

The main purpose of these essays creation was not only the facts life description, but the explanation of their social, political, ideological beliefs during the different stages of their own life. The most "controversive" moments of these autobiographical essays were the autobiographical writers' memoirs about their life in stormy revolutionary and post-revolutionary years. The authors had to repent in politically unconscious behavior in those times and convince them of their loyalty to the Communist authorities, for example, this can be traced in Mykhailo Yalovyi's autobiographical essay written on April 15, 1933: "To redeem myself, I ask you to consider both my revolutionary past, each step of which pervaded my sincere aspiration to serve the revolution and keep up with the Bolshevik party, and the petty-bourgeois character of the past, that negatively influenced the party excerpt of my political behavior" [11, p. 33-34]. However, even that could not save essayists from their further tragic fate. So, despite the "sincerely" written Communist autobiographical essay, Mykhailo Yalovyi was sentenced and shot in 1937, Mechyslav Hasko and Ostap Vyshnia were kept in reformatory labor camps.

Self-justification and self-repentance motives were present in other autobiographical essays of the 1930s, for example, in
Oleksandr Dovzhenko's essay dated 1939, in which the author publicly redeemed that he "entered the revolution in another the doors" [12, p. 25].

During 1959-1988s years in the 5-volumed "Soviet writers" there was a mass edition of ideologically approved autobiographical essays of the Soviet artists of the word. The heads of that project - B. Brainina and E. Nikitina - addressed contemporary writers, including the Ukrainian ones, with the request to introduce readers to the most basic, according to the authors' thought, information about themselves and their creative activities. In doing this the narrative form, the size and the actual filling fully depended on the authors' intentions, because the drafters did not limit the imagination of the authors. In the publication nineteen Russian language or translated from Ukrainian into Russian autobiographical essays of Ukrainian Soviet writers were saw the light, in particular, the works of Andrii Holovko, Ivan Le, Andrii Malyshko, Petro Panch, Leonid Pervomaiskyi, Maksym Rylskyi, Yurii Smolych, Volodymyr Sosiura, Oleksandr Korneichuk, Oles Honchar, Mikhailo Stelmakh and others.

The overwhelming majority of the authors (for example, Mykola Bazhan, Andrii Holovko, Ivan Le and others) wrote their autobiographical essays especially for this edition. The writers (Oleksandr Dovzhenko, Maksym Rylskyi, Ostap Vyshnia) used the written and printed earlier in Ukrainian language essays, somewhat altered and complemented them. In some cases, the compilers had to compose literary essays themselves, basing on the earlier autobiographical materials published in the form of personal data, the fragmentary memories and facts taken from autobiography archives, as it happened with autobiographical essays of Ivan Mykytenko (who was executed in 1937 as it was mentioned in a special note at the end of the text - "Life and creative path of the writer was tragically torn in the years of the personality cult. Ivan Kondratievich Mykytenko was illegally arrested and died in 1937 " [13, p. 470]) and Ivan Kocherha.

The hallmark of these autobiographical essays was that the authors didn't tell the whole truth about his real life more than they told about their lives. So, for example, Andrii Holovko, Maksym Rylskyi, Pavlo Tychyna, not so much reflected their real life story, they more tried to fit it in the dominant autobiographical canon. According to V. Kharkhun, the real biography of Andrii Holovko "did not correspond to the notions of the ideal candidate, the «initiator»" $[14$, p. 66] of the socialist canon, because "he was born into a wealthy family, he collaborated with fighters for the independence in the Ukrainian socialist revolutionary party, was involved in the family's tragedy (his wife's and daughter's death)" $[14$, p. 66] and, hence "a «new», corresponding to the writer's primary role biography, was written" $[14$, p. 66], "exemplary model of a socialist realist text" was written [14, p. 66], according to which, although the author had no proletarian origin, he has always become close to people and faithfully served the Soviet society. Similar fitting the canon can be traced on the example of the autobiographical essay by Maksym Rylskyi, who repeatedly emphasized the vicinity of his family to the lives of ordinary people.

Some part of autobiographers (as, for example, Pavlo Tychyna) had to resort to public self-criticism and self-justification because they didn't have the appropriate social origin.

The samples of quite cautious autobiographical essays were presented by Volodymyr Sosiura and Yurii Smolych, who limited themselves with presenting exact facts without focusing attention on some dangerous moments of their biography.

Most of the autobiographers filled their works with laudatory phrases as for the Soviet power, with the assurances of their loyalty to it, and for a large part of the authors it was one of the forms of self-defense. 
However, itshouldbenotedthatduring 1960-1970sautobiographical essays of completely different ideological and semantic content were being written, as, for example, Hryhir Tiutiunnyk's essay dated 1966, in which the author based on his personal life showed the real life of the Ukrainian peasants in 1930s-1940s, where he paid attention to the problem of hunger, injustice, poverty etc. The publication of such autobiographical essays became possible only in the late 1980s, and, according to $\mathrm{O}$. Halych, "it has substantially changed the situation in memoir writing of the XX century" [3, p. 153].

Of autobiographical essays of the 1990s typing and apologetics originated, but the essays become more and more individualized. So, in 1994-1995s in the 4-volumed anthology of Ukrainian literature and literary criticism of the XX century "The Ukrainian Word" among other materials several autobiographical essays of the Ukrainian (including Diaspora) authors were placed: Evhen Malaniuk, Vasyl Barka, Ihor Kalynets, Vasyl Holoborodko, Volodymyr Pidpalyi and others. Despite the different size and content-thematic content of these autobiographical texts, they were connected by their autobiographers' attention to the formation of their own worldview, the origins of patriotic Ukrainian-centered feelings.

Autobiographical essays again become informatively saturated and performed primarily cognitive function. For example, Marko Pavlyshyn and Yurii Lutskyi in their autobiographical essays, first, described the milestones of their life path, detailing their professional achievements, and, secondly, introduced the before unknown life of the Ukrainian diasporas in the USA, Canada and Australia to the Ukrainian readers.

Other autobiographical essays of the late of XX - early of XXI centuries came to be rich in facts as, the ones by Valerii Shevchuk, Roman Korohodskyi, Stepan Sapeliak. The mentioned above essayists for the first time in many years had received the possibility to tell the public literary about their real life over the past three decades. Valerii Shevchuk and Roman Korohodskyi soon elaborated their autobiographical essays in more lengthy personal history memoirs.

At the end of XX - beginning of XXI centuries the writers of the younger generation began to present their autobiographical essays (for example, Yurii Andrukhovych, Oksana Zabuzhko, Halyna Pahutiak and others). Their essays also had the distinct information-cognitive importance, but they focused primarily on the expression of their own life position and internal personal beliefs. In these works, the details of moral and psychological selfportrait prevailed over strict facts of the essayists' life milestones.

Conclusions. The Ukrainian autobiographical essay as a small genre of autobiographical prose didn't lose its topicality for the different stages of the development of the home memoir writing. With this, it preserved most of its typological and genreconstructing features the research of which is still waiting for more detailed literary studies.

\section{References:}

1. Мовчан Р.В. Самі про себе: автобіографії українських письменників 1920-х років. Слово і час. 2010. № 11. С. 79-89.

2. Федунь М.Р. Вітчизняна мемуаристика в Західній Україні першої половини XX століття: історичні тенденції, жанрова специфіка, поетика. Івано-Франківськ : Прикарпатський національний університет імені Василя Стефаника, 2010. 452 с.

3. Галич О.А. Українська документалістика на зламі тисячоліть: специфіка, генеза, перспективи. Луганськ : Знання, 2001. 246 с.

4. Пустовіт В.Ю. Проблеми націєтворення в мемуарному дискурсі вітчизняних письменників XIX століття. Луганськ : Знання, 2008. 284 с.

5. Черкашина Т.Ю. Мемуарно-автобіографічна проза XX століття: українська візія. Харків : Факт, 2014. 380 с.
6. Література non fiction: теоретичний вимір / упор. Т.Ю. Черкашина. Київ : Видавничий дім Дмитра Бураго, 2018. 272 с.

7. Мовчан Р.В. Безповоротна втрата? (словник українських письменників Миколи Плевака). Слово і час. 1995. № 4. С. 27-32.

8. Автобіографія Майка Йогансена, того Йогансена, що оздобив прологом, епілогом та інтермедіями 133 книгу «Літературного ярмарку». Йогансен М. Вибрані твори. Київ : Смолоскип, 2009. С. 716-718

9. Поліщук В.Л. Дороги моїх днів. Блажен, хто може горіти.... автобіографія, щоденники, листи. Рівне : Азалія, 1997. С. 6-26.

10. Архів Розстріляного Відродження: матеріали архівно-слідчих справ українських письменників 1920-1930-х років / упор. : О. та Л. Ушкалові. Київ : Смолоскип, 2010. 456 с.

11. Яловий М.С. Автобіографія. Архів Розстріляного Відродження: матеріали архівно-слідчих справ українських письменників 1920-1930-х років // упор. : О. та Л. Ушкалові. Київ : Смолоскип, 2010. С. 17-34.

12. Довженко О.П. Автобіографія. Довженко О.П. Твори : в 5 т. Київ : Дніпро, 1964. Т. 1. С. 20-35.

13. Микитенко И.К. О себе. Советские писатели. Москва : Художественная литература, 1966. Т. 3. С. 460-470.

14. Хархун В.П. Соцреалістичний канон в українській літературі: генеза, розвиток, модифікації. Ніжин : ТОВ Гідромакс, 2009. 508 с.

Черкашина Т. Ю. Український автобіографічний нарис: історія розвитку

Анотація. Статтю присвячено дослідженню історії розвитку українського автобіографічного нарису. Зазначено, що жанр автобіографічного нарису в українській літературі бере свій початок із XVI століття - iз часу появи латиномовного життєписного нарису Станіслава Оріховського (Роксолана). Надалі цей жанр було представлено на всіх історичних етапах розвитку української літератури. У статті аналізуються автобіографічні нариси Тараса Шевченка, Олександра Потебні, Степана Васильченка, Майка Йогансена, Олександра Довженка, Григора Тютюнника та інших літераторів. Вказується на прагматичну мету написання нарисових творів, від якої залежали вибір форми, структури та ступеня художності нарису. Упродовж століть український автобіографічний нарис був представлений фактографічними, науковими, біобібліографічними, ігровими, типізованими, апологетичними різновидами. Характерними для цього жанру стали невеликий обсяг автобіографічної оповіді, вільна композиція, відсутність загальновизнаних правил побудови, прагматична настанова оповіді, сильне особистісне начало, фактографічність, документальність. Більшість українських автобіографічних нарисів писалися 3 апологетичною або пізнавальною метою. Автобіографічні нариси межі XIX-XX століть були здебільшого літературоцентричними. Нерідким було неодноразове звернення авторів до цього жанру, вони писали 3 невеликим часовим інтервалом для різних адресатів. Автобіографічні нариси цього періоду часто піддавалися цензурі й редакторському втручанню. Розквіт жанру припав на 1920-ті роки. Нарисовці цього періоду вільно виражали свої думки, автобіографічні нариси були засобом самовираження письменників. Для українських автобіографічних нарисів 1930-1950-х років характерні мотиви самокаяття, самозвинувачення. Більшість автобіографічних нарисів 1930-1960-х років були типізованими та апологетичними. 3 1990-х років українські автобіографічні нариси стають більш інформативно насиченими.

Ключові слова: автобіографічний нарис, українське автобіографічне письмо, науковий автобіографічний нарис, літературний автобіографічний нарис, прагматична мета, фактографічність, апологетика. 